\title{
Respiratory symptoms and fractional exhaled nitric oxide (FeNO) among students in Penang, Malaysia in relation to signs of dampness at school and fungal DNA in school dust
}

\author{
Dan Norbäck ${ }^{\mathrm{a}, *}$, Jamal Hisham Hashim ${ }^{\mathrm{b}, \mathrm{c}}$, Zailina Hashim ${ }^{\mathrm{d}}$, Gui-Hong Cai ${ }^{\mathrm{a}}$, Vinoshini Sooria ${ }^{\mathrm{e}}$, \\ Syazwan Aizat Ismail ${ }^{\mathrm{e}, \mathrm{f}}$, Gunilla Wieslander ${ }^{\mathrm{a}}$ \\ a Uppsala University, Department of Medical Science, Occupational and Environmental Medicine, University Hospital, 75185 Uppsala, Sweden \\ ${ }^{\mathrm{b}}$ United Nations University-International Institute for Global Health, 56000 Kuala Lumpur, Malaysia \\ c Department of Community Health, National University of Malaysia, 56000 Kuala Lumpur, Malaysia \\ d Department of Environmental and Occupational Health, Faculty of Medicine and Health Sciences, Universiti Putra Malaysia, 43400 UPM, Serdang, Selangor, Malaysia \\ e Department of Community Health, Faculty of Medicine and Health Sciences, Universiti Putra Malaysia, 43400 UPM Serdang, Selangor, Malaysia \\ ${ }^{\mathrm{f}}$ Environmental Health, Allied Health Science College Sg Buloh, Ministry of Health Malaysia, 47000 Sungai Buloh, Selangor, Malaysia
}

\section{H I G H L I G H T S}

- Elevated FeNO, a marker of lower airway inflammation, was found in many students.

- Signs of dampness in the classroom were related to airway infections among students.

- Students in classrooms with signs of dampness had 31\% higher FeNO values.

- Higher quantities of DNA from Aspergillus versicolor were related to higher FeNO.

- DNA from Aspergillus versicolor were related to asthma and respiratory symptoms.
G R A P H I C A L A B S T R A C T

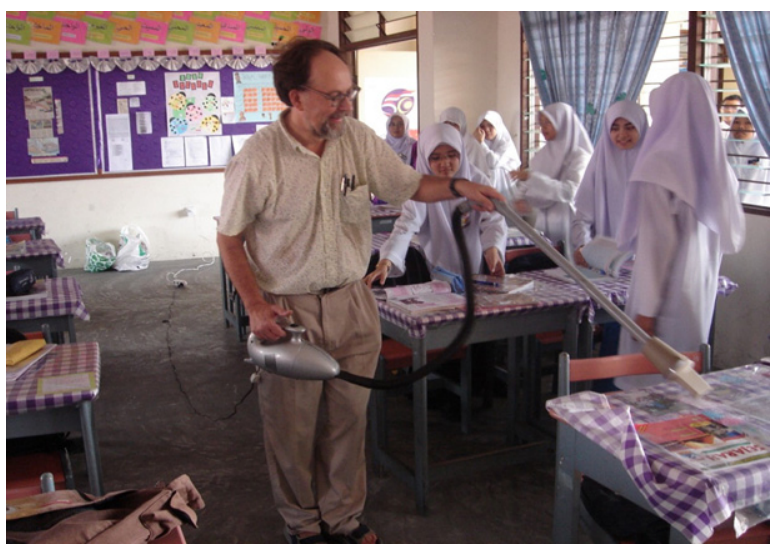

\section{A B S T R A C T}

Few health studies exist on dampness and mould in schools in the tropics. We studied associations between fraction of exhaled nitric oxide (FeNO), respiratory symptoms and airway infections among students and dampness and fungal DNA in schools in Malaysia. A total of 368 randomly selected students from 32 classrooms in 8 secondary schools in Penang, Malaysia, participated (58\% participation rate). Information on current respiratory symptoms and the home environment was collected by a standardised questionnaire. FeNO was measured by NIOX MINO (50 ml/min). The classrooms were inspected and dust was collected by vacuuming on special filters and was analysed for five fungal DNA sequences by quantitative PCR. Linear mixed models and 3-level multiple logistic regression (school, classroom, student) were applied adjusting for demographic data and the home environment. Totally $10.3 \%$ reported doctor's diagnosed asthma, $15.1 \%$ current wheeze, $12.4 \%$ current asthma, $37.3 \%$ daytime breathlessness, $10.2 \%$ nocturnal breathlessness, $38.9 \%$ airway infections and $15.5 \%$ had pollen or furry

\footnotetext{
* Corresponding author at: Department of Medical Sciences, Occupational and Environmental Medicine, University Hospital, SE-751 85 Uppsala, Sweden.

E-mail address: dan.norback@medsci.uu.se (D. Norbäck).
} 
School environment Asthma

Mould

Children pet allergy. The geometric mean of FeNO was $19.9 \mathrm{ppb}$ and $45 \%$ had elevated FeNO ( $>20 \mathrm{ppb}$ ). Boys had higher levels of FeNO. Chinese had less daytime breathlessness than Malay ( OR $=0.30: p<0.001)$. Indoor carbon dioxide levels were low (380-720 ppm). Dampness was observed in 18\% of the classrooms and was associated with respiratory infections ( $\mathrm{OR}=3.70 ; 95 \% \mathrm{CI} 1.14-12.1)$ and FeNO $(p=0.04)$. Aspergillus versicolor DNA was detected in $67 \%$ of the classrooms. Higher numbers of Aspergillus versicolor DNA in classroom dust were associated with wheeze $(p=0.006)$, current asthma $(p=0.002)$, respiratory infections $(p=0.005)$ and elevated FeNO levels $(p=0.02)$. In conclusion, respiratory symptoms were common among the students and the high FeNO levels indicate ongoing airway inflammation. Building dampness and the mould Aspergillus versicolor in schools in Malaysia can be risk factors for impaired respiratory health among the students.

(c) 2016 Elsevier B.V. All rights reserved.

\section{Introduction}

The school environment is important for school children but can be contaminated by various pollutants such as chemicals, furry pet allergens, mould and bacteria (Daisey et al., 2003; Salo et al., 2009). Dampness and indoor mould can cause respiratory illness (WHO, 2009) but there is a lack of epidemiological studies using molecular methods to assess mould exposure (Norbäck and Cai, 2015). Moreover, few school environment studies exist that have studied associations between observed signs of dampness in schools and respiratory health in the students (Mi et al., 2006; Borras-Santos et al., 2013). Quantitative Polymerase Chain Reaction (qPCR) can give quantitative data on levels of most indoor moulds, irrespectively of viability (Haugland et al., 2004; Vesper et al., 2005). The highest indoor fungal DNA levels are found near the equator (Norbäck and Cai, 2011) but there are few studies on associations between mould in schools in the tropics and respiratory health in students. In a previous study from Johor Bahru, Malaysia, we found associations between fungal DNA in schools and respiratory symptoms among students, especially for the mould Aspergillus versicolor and the gram-positive bacteria Streptomyces sp. (Cai et al., 2011). Similar results were found in a multicentre school study within the European Union (Simoni et al., 2011).

Fraction of exhaled nitric oxide (FeNO) has recently been used in epidemiological studies in Asia (Xu et al., 2011; Zhao et al., 2013; Lim et al., 2015). FeNO is a biomarker of TH2 driven lower airway inflammation linked to allergic asthma (Alving and Malinovschi, 2010) rhinitis (Xu et al., 2011, Zhao et al., 2013; Lim et al., 2015a) and sick building syndrome (SBS) symptoms (Lim et al., 2015b). FeNO has been measured among office workers in Malaysia (Lim et al., 2015, Lim et al., 2016) but we found no previous publications from Malaysia, or any other tropical country, on associations between FeNO and the school environment.

The first aim was to investigate associations between selected demographic data and respiratory symptoms and infections and to measure the fraction of exhaled nitric oxide (FeNO) among junior high school students in Penang, Malaysia. The second aim was to study associations between observed signs of dampness in the classrooms and respiratory symptoms and infections and FeNO among the students. The third aim was to measure the levels of five sequences of fungal DNA in vacuumed dust from the students' classrooms and to study associations between fungal DNA in the classrooms, and respiratory symptoms, airway infections and FeNO levels.

\section{Material and methods}

\subsection{Ethics statement}

The study proposal was approved by the Medical Research and Ethics Committee of the National University of Malaysia and all participants gave informed consent. We obtained written consent from the students after explaining to them the purpose of the study. The records of study respondents' signatures are kept at the National University of Malaysia. The students brought the questionnaire home to answer it together with their parents or guardians, and we got signatures of approval from the students as well as from the parents. The medical study and collection of dust from the schools had permission from Penang State Health Department, the principal of each school and the head teacher of each class involved in the study.

\subsection{Study population}

A total of 8 junior high schools were randomly selected in the state of Penang, Malaysia. Four schools were selected from Penang Island and four from the mainland (Northern Seberang Perai). Four classes of grade two students were randomly selected in each school and 20 students were randomly selected from each class. The study was performed in October-November 2012.

\subsection{Assessment of health data}

We used a self-administered questionnaire from previous school studies (Smedje et al., 1997; Cai et al., 2011; Mi et al., 2006; Zhao et al., 2008; Norbäck et al., 2014) with questions on doctors' diagnosed asthma, current asthma, allergies, respiratory symptoms and airway infections obtained from the ISAAC study (Asher et al., 2006), the European Respiratory Health Survey (ECRHS) (Janson et al., 2001) and our previous school studies (Smedje et al., 1997; Cai et al., 2011; Mi et al., 2006; Zhao et al., 2008; Norbäck et al., 2014). There were (yes/ no) questions on doctors' diagnosed asthma, current asthma medication (sprays, tablets etc.) and any asthma attack during the last 12 months. Moreover there were (yes/no) questions on respiratory symptoms the last 12 months including: 1) wheezing or whistling in the chest 2) wheeze or whistling in the chest combined with breathlessness 3 ) daytime attacks of shortness of breath during exercise or while resting (2 questions). 4) Night-time awakening with attacks of breathlessness or tightness in the chest. Moreover, there were yes/no questions on current smoking, allergy to cat, dog and pollen and parental allergy/asthma. Finally, there was one question on respiratory infections during the last 3 months and two questions on the home environment (environmental tobacco smoke and dampness/mould). The questionnaire was distributed to the selected pupils the same week as the technical measurements and answered with help of the parents at home. Then staff from the research team went through the questionnaires during a face-to-face interview with the students to clarify any uncertainly in the questions. The student had no information on the environmental data when they answered the questionnaires.

\subsection{Inspection of the schools environment and dust sampling}

Details on the school building, age and signs of dampness or mould were noted. Temperature $\left({ }^{\circ} \mathrm{C}\right)$, Relative Humidity $(\mathrm{RH}, \%)$ and $\mathrm{CO}_{2}$ ( $\mathrm{ppm}$ ) were measured in the classrooms during normal activities for 1 h with Q-TrakTM monitors (TSI Incorporated, St. Paul, Minnesota, USA). Settled dust was collected from floors, desks and chair (mixed sample) by a $400 \mathrm{~W}$ vacuum cleaner provided with a special dust collector (ALK Abello, Copenhagen, Denmark) as in previous school studies 
(Smedje et al., 1997; Zhao et al., 2008; Norbäck et al., 2014). The dust was sieved through $0.3-\mathrm{mm}$ mesh screen to obtain the fine dust, weighed, and analysed for fungal DNA. All filters were stored at $-20{ }^{\circ} \mathrm{C}$ until sieving and the sieved dust samples were stored at $-80{ }^{\circ} \mathrm{C}$.

\subsection{Analysis of fungal DNA in vacuumed dust}

The method for analysis of fungal DNA has been previously described (Cai et al., 2011; Norbäck and Cai, 2011; Norbäck et al., 2014). Briefly fungal DNA was extracted from $10 \mathrm{mg}$ of sieved dust and five multiplex reactions were performed in five separate tubes targeting the DNA of the following species: total fungi, Aspergillus spp. plus Penicillium spp. (Asp/Pen), Aspergillus versicolor (A. versicolor), Stachybotrys chartarum (S. chartarum) and Streptomyces spp. The oligonucleotides used for amplification and detection were designed by Dynamic Code (Linköping, Sweden). The sequence "total fungal DNA" covers a wide range of indoor fungi, mainly Ascomycetes, but it does not cover all indoor fungi. The fungal DNA levels were presented as target copies/g dust.

The reaction targeting $A$. versicolor simultaneously amplified an internal positive control that was used to detect PCR inhibition. There were no inhibition detected in any sample. DNA was extracted from the samples using the YeaStar ${ }^{\mathrm{TM}}$ Genomic DNA Kit (Zymo Research, Orange, CA) according to the manufacturer's instructions. The oligonucleotides used for amplification and detection were designed using the design software Primer Express 2.0 (Applied Biosystems, Foster City, CA USA). Primers and probes for total fungal DNA, A. versicolor and $S$. chartarum DNA are in the region of internal transcribed spacer 1, 5.8 S rRNA and internal transcribed spacer 2. Primers and probes for Asp/ Pen DNA are in the gene for 28S rRNA and for Streptomyces DNA in the gene for 16S rRNA. GenBank accession numbers AB030916.1, AB002079.1, AJ639854.1, U00970.1, AF548081.1 and AF548082.1 were used to design the test for total fungal DNA: GenBank accession numbers AF454157.1, Z48340.1, DQ914661.1, AF027863.1, AF433079.1, DQ123641.1, U29632.1, AF0344456.1, AF034461.1, AF034455.1, AF033395.1 and U29555.1 were used to design the test for Asp/Pen DNA. GenBank accession number AJ937749.1 was used to design the test for A. versicolor DNA: GenBank accession number AY180260.1 was used to design the test for S. chartarum DNA: GenBank accession numbers EF017715.1 and AL939114.1 were used to design the test for Streptomyces DNA: Amplification and detection was performed on a 7300 Real-time PCR Instrument (Applied Biosystems, Foster City, CA USA) using the Taqman1 Universal Master Mix (Applied Biosystems, Foster City, CA USA). A list of species captured by the different fungal DNA sequences is available in the online S1 Appendix of our previous publication (Norbäck et al., 2016a,b). The total fungal DNA sequence was common for 7 Acremonium sp., 61 Alternaria sp. (including A. alternata), 86 Aspergillus sp. (including $A$. fumigatus but not $A$. versicolor), Aureobasidium mansonii, Aurerobasidium pullulans, Cerebella andropogonis, 38 Cladosporium sp. (including C. herbarium), 14 Curvularia sp., Cylindorcarpon lichenicola, 3 Davidiella sp., Epicoccum nigrum, 27 Eupenicillium sp., 6 Eurotium sp., 8 Fusarium sp., Hemicarpenteles paradoxus, Mycosphaerella macrospora, Mycosphaerella tassiana, Nectria haematococca, 17 Neosartorya sp. 15 Paecillomyces sp., 157 Penicillium sp., 3 Petromyces sp., Ramichloridium mackenziei, 9 Rhinocladiella sp., Sclerocleista ornata, 12 Stachybotrys sp., 3 Thermoascus sp. and 48 Trichoderma sp. We have used the term "total fungal DNA" for this sequence since it coverers a wide range of indoor fungi, mainly Ascomycetes, but it does not cover all indoor fungi. The Asp/Pen DNA sequence was common for 37 Aspergillus sp. (including A. fumigatus but not $A$. versicolor), Davidiella tassiana, 14 Eupenicillium sp., 15 Eurotium sp., Hemicarpenteles paradoxus, 7 Neosartorya sp., Paecilomyces variotii, Paracoccidioides cerebriformis, 62 Penicillium sp. and Thermoascus aurantiacus. The Streptomyces DNA sequence was common for 187 Streptomyces sp., as well as Micromonospora megalomicea. The A. versicolor DNA sequence was specific for A. versicolor only. The $S$. chartarum DNA sequence was specific for Stachybotrys chartarum and Stachybotrys chlorohalonata but not Memnoninella echinata.

\section{Statistical methods}

Differences in symptom prevalence between males and females and between subjects with and without doctors' diagnosed asthma were analysed by Chi-square test. Differences in amount of dust and levels of fungal DNA in vacuumed dust in classrooms, with and without signs of dampness, was analysed by Mann-Whitney $U$ test. Correlations between exposure variables were analysed by Kendall's Tau beta. Initially, associations between demographic data and symptoms were examined by multi-level multiple logistic regression, keeping sex, ethnicity, smoking, a history of atopy and parental asthma/allergy in the models. Three levels were used, individual level, classroom level and school level. Then we analysed associations between signs of dampness in the classrooms, amount of dust in the classrooms, fungal DNA in vacuumed dust and symptoms as well as categorized FeNO (normal vs. elevated levels), adjusting for gender, sex, smoking, a history of atopy and parental asthma/allergy. A FeNO level above $20 \mathrm{ppb}$ was considered as an elevated level, in accordance with the American Thoracic Society (ATS) guidelines for children (Dweik et al., 2011). As a next step, we analysed associations in mutually adjusted 3-level multilevel logistic regression models with additional adjustment for two home environment factors, environmental tobacco smoke (ETS) and dampness/mould, including exposure variables that had $p<0.1$ in the initial analysis. Finally, FeNO was ${ }^{10} \log$-transformed and analysed as a dependent variable by linear mixed models adjusting for the same variables as in the logistic regression models and then adjusted for the two home environment factors in mutually adjusted models, including exposure variables with $p<0.1$. Odds ratio (OR) with $95 \%$ confidence interval $(95 \% \mathrm{CI})$ was calculated for the logistic regression analyses. Antilog beta value with $95 \% \mathrm{CI}$ was calculated from the linear mixed models by calculating antilog $(10 \times)$ values. Statistics were performed with the STATA 13.0 statistical package using two-tailed tests and a $5 \%$ significance level.

\section{Results}

\subsection{Personal characteristics and symptoms}

A total of 368 students participated (58\% of the recruitment) and the mean age was 14 years (range 14-16 years). Based on the questionnaires, the children were 70\% Malay, 15\% Chinese and 15\% Indian. The prevalence of current smoking was $2.7 \%$ ( $0 \%$ in girls and $6.0 \%$ in boys). Atopy in the cohort was reported as pollen allergy at $8.2 \%$, cat allergy at $7.9 \%$, dog allergy at 3.0\%, and either pollen, cat or dog allergy at $15.5 \%$. A total of $24.5 \%$ of the students had a father or mother with asthma or allergic rhinitis.

Current asthma was defined as having either asthma medication, asthma attacks or wheeze with breathlessness last 12 months (12.4\%). A total of $5.4 \%$ of the students had current asthma medication, $5.4 \%$ have had an asthma attack in the last 12 months, and $8.8 \%$ reported a combination of wheeze and breathlessness in the last 12 months (Daytime attacks of breathlessness occurring after exercise was common at $31.2 \%$, while attacks at rest were less common at $16.4 \%$ ).

Table 1 provides the data on the prevalence of asthma, respiratory symptoms and FeNO concentrations, as well as the statistical analysis stratified for gender and doctors' diagnosed asthma. In the bivariate analysis, girls had a higher prevalence of daytime attacks of breathlessness $(p=0.006)$ while boys had more often had elevated FeNO concentrations $(p=0.003)$. Geometric mean for FeNO was $19.9 \mathrm{ppb}$ and $54.6 \%$ had a FeNO value above $20 \mathrm{ppb}$. Elevated FeNO levels ( $>20 \mathrm{ppb}$ ) and all types of respiratory symptoms, except airway infections, were more common among students with doctors' diagnosed asthma. The majority 
Table 1

Prevalence of asthma and respiratory symptoms among pupils $(N=348)$ from eight junior high schools in Penang, Malaysia.

\begin{tabular}{|c|c|c|c|c|c|c|c|}
\hline Symptoms & $\begin{array}{l}\text { Overall } \\
(\%)\end{array}$ & $\begin{array}{l}\text { Male } \\
(\%)\end{array}$ & $\begin{array}{l}\text { Female } \\
(\%)\end{array}$ & $p$-Value & $\begin{array}{l}\text { Doctors' diagnosed } \\
\text { asthma } \\
\text { Nos }\end{array}$ & $\begin{array}{l}\text { Doctors' diagnosed } \\
\text { asthma } \\
\text { Yes }\end{array}$ & $p$-Value \\
\hline \multicolumn{8}{|l|}{ Study variables } \\
\hline Doctor's diagnosed asthma & 10.3 & 12.5 & 8.5 & 0.21 & NA & NA & \\
\hline Wheeze or whistling in the chest last 12 months & 15.1 & 14.9 & 15.2 & 0.93 & 11.0 & 50.0 & $<0.001$ \\
\hline Current asthma $^{\mathrm{a}}$ & 12.4 & 11.4 & 13.2 & 0.60 & 6.7 & 60.5 & $<0.001$ \\
\hline $\begin{array}{l}\text { Daytime attacks of breathlessness last } 12 \text { months (rest or } \\
\text { exercise) }\end{array}$ & 37.3 & 29.7 & 43.7 & 0.006 & 34.4 & 63.9 & 0.001 \\
\hline Nocturnal attacks of breathlessness last 12 months & 10.2 & 8.5 & 11.6 & 0.34 & 8.0 & 30.6 & $<0.001$ \\
\hline Airway infections in the last 3 months & 38.9 & 39.2 & 30.5 & 0.88 & 38.2 & 44.7 & 0.43 \\
\hline Elevated FeNO (>20 ppb) & 45.4 & 53.7 & 38.0 & 0.003 & 42.4 & 70.3 & 0.001 \\
\hline
\end{tabular}

of the students with doctors' diagnosed asthma had respiratory symptoms, current asthma and elevated FeNO concentrations, but even among those without doctors' diagnosed asthma, daytime attacks of breathlessness (34.4\%) and elevated FeNO levels (42.4\%) were common.

\subsection{Descriptive data on the school environment}

The schools were concrete buildings with a concrete floor without any paint or floor covering. None of the schools had mechanical ventilation or air conditioning units in the classrooms but there were electric fans on the ceiling and glass window panes on both sides that were kept open during lectures. Smoking was not allowed. The mean room temperature was $28^{\circ} \mathrm{C}$ (range of $25-30^{\circ} \mathrm{C}$ ), similar as the mean outdoor temperature $\left(29^{\circ} \mathrm{C}\right)$. The mean indoor relative air humidity was $79 \%$ (range of $67-88 \%$ ), similar as the mean outdoor air humidity (75\%). The mean $\mathrm{CO}_{2}$ concentration in the classrooms was $425 \mathrm{ppm}$ (range of 380-720 ppm), and 407 ppm outdoors. All dust samples contained total fungal DNA and Asp/Pen DNA. A. versicolor DNA was detected in $67 \%$ of the samples and Streptomyces DNA was detected in $94 \%$ of the samples (Table 3). S. chartarum DNA in vacuumed dust was found in one classroom only, at very low levels ( $5 \mathrm{CE} / \mathrm{mg}$ dust) and was not further analysed in the regression models. A total of seven classroom (22\%) had signs of water leakage in the ceiling but none had visible indoor mould growth, and totally 65 students (17.7\%) were from these damp classrooms. There was a tendency of increased levels of total fungal DNA ( $p=0.07)$ and Streptomyces DNA $(p=0.08)$ in classrooms with signs of dampness but no significant differences for the other DNA sequences of amount of fine dust (Table 2). There was a significant correlation between total fungal DNA and Asp/Pen DNA (Kendal Tau beta $0.64 ; p<0.001$ ) and between total fungal DNA and Streptomyces DNA (Kendal Tau beta $0.34 ; p=0.08$ ) but no other significant associations between fungal DNA sequences or between the amount of fine dust and any fungal DNA sequences.

\subsection{Symptoms in relation to personal characteristics}

In the logistic regression models, doctors' diagnosed asthma was more common among students with a history of atopy $(p<0.001)$ and parental asthma/allergy $(p=0.008)$. Wheeze was associated with a history of atopy $(p=0.007)$ and parental asthma/allergy $(p=$ 0.04 ). Current asthma was associated with current smoking ( $p=$ 0.01 ) and a history of atopy $(p=0.006)$. Daytime attacks of breathlessness was more common in girls $(p=0.006)$ and less common in Chinese students $(p=0.001)$. Night time attacks of breathlessness was associated with a history of atopy $(p=0.02)$, only. No associations were found between the demographic data and airway infections (Table 3).

\subsection{Symptoms and FeNO in relation to signs of dampness and fungal DNA in vacuumed dust}

As a next step, we analysed associations between exposure in the school and respiratory symptoms, airway infections and FeNO. We used 3-level (student, classroom, school) using multiple logistic regression models for symptoms and categorized FeNO (normal vs. elevated level; $>20 \mathrm{ppb}$ ). There was a positive association between signs of dampness in the classroom and airway infections. There was a negative association between the amount of fine dust in the classroom and current asthma ( $p=0.02$ ). There were positive associations between the concentration of Aspergillus versicolor DNA in vacuumed dust and current wheeze ( $p=0.006)$, current asthma $(p=0.01)$, airway infections last 3 months $(p=0.005)$ and elevated FeNO levels $(p=0.04)$ (Table 4).

A total of $48.9 \%$ had ETS at home and $34.8 \%$ had dampness or mould at home defined as either water leakage, signs dampness on the floor, visible indoor mould or mouldy odour (Norbäck et al., 1999). Mutual adjustment including school exposure variables with $p<0.1$ and further adjustments for the two home environment factors gave similar associations. Signs of dampness in the classroom was still associated with airway infections and Aspergillus versicolor DNA was still associated with wheeze, current asthma, airway infections and elevated FeNO levels. However, the associations between amount of fine dust and wheeze and current asthma were no longer statistically significant (Table 5). Finally, associations between FeNO as a continuous variable $\left({ }^{10} \log\right.$ transformed to get normally distributed data) and the exposure variables were analysed by linear mixed models, adjusting for the same

Table 2

Fungal DNA in vacuumed dust from classrooms $(N=32)$ in junior high schools in Penang, Malaysia.

\begin{tabular}{|c|c|c|c|c|}
\hline Dust exposure at school & AM & GM & $95 \% \mathrm{CI}$ of $\mathrm{GM}$ & Classrooms with levels above the detection limit (\%) \\
\hline Amount of fine dust $(\mathrm{g})$ & 3.76 & 3.27 & $3.10-3.45$ & 100 \\
\hline \multicolumn{5}{|c|}{ Fungal DNA in dust (target copies/g dust) } \\
\hline Total fungal DNA & $9.42 * 10^{4}$ & $7.32 * 10^{4}$ & $6.79-7.89 * 10^{4}$ & 100 \\
\hline Asp/Pen DNA & $4.61 * 10^{4}$ & $3.34 * 10^{4}$ & $3.08-3.63 * 10^{4}$ & 100 \\
\hline A. versicolor DNA & 65 & 15 & NA & 67 \\
\hline Streptomyces DNA & 10 & 7 & NA & 94 \\
\hline
\end{tabular}

$\mathrm{AM}=$ arithmetic mean, $\mathrm{GM}=$ geometric mean, $\mathrm{GSD}=$ geometric standard deviation.

Asp/Pen: Aspergillus/Penicillium, A. versicolor: Aspergillus versicolor, S. Chartarum: Stachybotrys chartarum. 
Table 3

Associations between respiratory health among students $(N=368)$ from junior high schools in Penang, Malaysia and demographic data.

\begin{tabular}{|c|c|c|c|c|c|c|}
\hline Type of factors & $\begin{array}{l}\text { Doctors' diagnosed } \\
\text { asthma OR }(95 \% \mathrm{CI})\end{array}$ & $\begin{array}{l}\text { Wheeze OR } \\
(95 \% \mathrm{CI})\end{array}$ & $\begin{array}{l}\text { Current } \\
\text { asthma } \\
\text { OR }(95 \% \mathrm{CI})^{\mathrm{a}}\end{array}$ & $\begin{array}{l}\text { Daytime attacks of } \\
\text { breathlessness OR (95\% CI) }\end{array}$ & $\begin{array}{l}\text { Nocturnal attacks of } \\
\text { breathlessness OR }(95 \% \mathrm{CI})\end{array}$ & $\begin{array}{l}\text { Respiratory infections } \\
\text { OR }(95 \% \mathrm{CI})\end{array}$ \\
\hline Female gender & $0.67(0.32-1.39)$ & $\begin{array}{l}1.15 \\
(0.62-2.13)\end{array}$ & $\begin{array}{l}1.53 \\
(0.76-3.09)\end{array}$ & $1.93(1.21-3.08)^{* *}$ & $1.55(0.72-3.36)$ & $0.99(0.64-1.53)$ \\
\hline Chinese & $0.52(0.15-1.88)$ & $\begin{array}{l}1.72 \\
(0.78-3.77)\end{array}$ & $\begin{array}{l}0.58 \\
(0.19-1.76)\end{array}$ & $0.30(0.14-0.63)^{* * *}$ & $0.16(0.02-1.25)$ & $0.98(0.53-1.82)$ \\
\hline Indian & $1.42(0.55-3.68)$ & $\begin{array}{l}0.96 \\
(0.39-2.35)\end{array}$ & $\begin{array}{l}1.07 \\
(0.43-2.64)\end{array}$ & $0.55(0.28-1.07)$ & $1.40(0.55-3.54)$ & $1.10(0.60-2.02)$ \\
\hline Tobacco smoking & $0.54(0.06-5.31)$ & $\begin{array}{l}2.74 \\
(0.61-12.4)\end{array}$ & $\begin{array}{l}6.21 \\
(1.47-26.1)^{*}\end{array}$ & $0.51(0.10-2.60)$ & $2.85(0.49-16.7)$ & $2.35(0.63-8.76)$ \\
\hline $\begin{array}{l}\text { Pollen or furry } \\
\text { pet allergy (atopy) }\end{array}$ & $4.09(1.92-8.73)^{* * *}$ & $\begin{array}{l}2.62 \\
(1.31-5.25)^{* *}\end{array}$ & $\begin{array}{l}2.92 \\
(1.37-6.23)^{* *}\end{array}$ & $1.30(0.70-2.42)$ & $2.74(1.20-6.29)^{*}$ & $1,18(0.66-2.13)$ \\
\hline $\begin{array}{l}\text { Parental } \\
\text { asthma/allergy }\end{array}$ & $2.76(1.31-5.82)^{* * *}$ & $\begin{array}{l}1.97 \\
(1.03-3.77)^{*}\end{array}$ & $\begin{array}{l}1.53 \\
(0.75-3.14)\end{array}$ & $1.61(0.96-2.69)$ & $1.77(0.82-3.84)$ & $1.36(0.82-2.24)$ \\
\hline
\end{tabular}

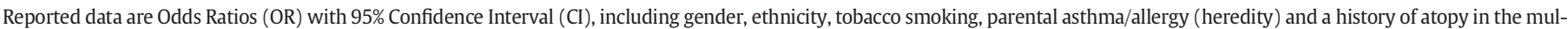
tiple logistic regression models.

Ethnicity was analysed as categorical variable with Malay race as reference category.

a Current asthma medication, asthma attacks last 12 months or wheeze with breathlessness last 12 months.

$* p<0.05$.

** $p<0.01$.

*** $p<0.001$.

confounders as in the logistic regression models. Signs of dampness in the classroom was associated with elevated FeNO $(p=0.04)$ and Aspergillus versicolor DNA ( $p=0.03$ ). Further adjustments by mutually adjusted models and adding the two home exposure variables (ETS and dampness/mould) gave similar associations. The values shows that having signs of dampness in the classroom is associated with $31 \%$ higher FeNO values, and an increase of Aspergillus versicolor DNA by 100 target copies/g dust is associated with 12\% increase of FeNO.

\section{Discussion}

Respiratory symptoms were common and $45 \%$ of the students had FeNO levels exceeding the reference value of $20 \mathrm{ppb}$ for children suggested by ATS (Dweik et al., 2011). Even among those without doctors' diagnosed asthma, many (42\%) had elevated FeNO levels. High levels of
FeNO have previously been reported among office workers in Malaysia (Lim et al., 2015). A total of $10 \%$ had doctors' diagnosed asthma, a somewhat lower prevalence than the $13 \%$ found in our previous school study from Johor Bahru, Malaysia (Cai et al., 2011).

Tobacco smoking was more common in boys than girls and related to current asthma. Daytime attacks of breathlessness was more common in girls and less common in Chinese students. Gender differences and associations for smoking and the lower prevalence of some respiratory symptoms among Chinese were similar to previous studies from Johor Bahru (Cai et al., 2011; Norbäck et al., 2014). As expected, parental asthma/allergy and a history of atopy were important determinants of respiratory health.

About one fifth of the student had signs of dampness in their classroom and these classroom had a two times higher levels of total fungal DNA and Streptomyces DNA. The signs of dampness were signs of water

Table 4

Associations between respiratory health among pupils $(N=368)$ in Penang, Malaysia and fungal DNA and amount of fine dust in the classroom.

\begin{tabular}{|c|c|c|c|c|c|c|c|}
\hline $\begin{array}{l}\text { Type of } \\
\text { exposure }\end{array}$ & $\begin{array}{l}\text { Wheeze } \\
\text { OR }(95 \% \text { CI })\end{array}$ & $\begin{array}{l}\text { Current } \\
\text { asthma } \\
\text { OR }(95 \% \mathrm{CI})^{\mathrm{a}}\end{array}$ & $\begin{array}{l}\text { Daytime attacks of } \\
\text { breathlessness } \\
\text { OR }(95 \% \mathrm{CI})\end{array}$ & $\begin{array}{l}\text { Nocturnal attacks of } \\
\text { breathlessness } \\
\text { OR }(95 \% \mathrm{CI})\end{array}$ & $\begin{array}{l}\text { Respiratory } \\
\text { infections } \\
\text { OR }(95 \% \mathrm{CI})\end{array}$ & $\begin{array}{l}\text { Elevated FeNO } \\
(>20 \mathrm{ppb}) \\
\text { OR }(95 \% \mathrm{CI})\end{array}$ & $\begin{array}{l}\text { Antilog FeNO } \\
\text { beta }(95 \% \mathrm{CI})\end{array}$ \\
\hline $\begin{array}{l}\text { Amount of fine } \\
\text { dust }\end{array}$ & $\begin{array}{l}0.83 \\
(0.68-1.02)^{(*)}\end{array}$ & $\begin{array}{l}0.79 \\
(0.65-0.96)^{*}\end{array}$ & $0.90(0.79-1.03)$ & $0.98(0.81-1.17)$ & $1.01(0.81-1.28)$ & $0.95(0.85-1.07)$ & $0.98(0.94-1.03)$ \\
\hline \multicolumn{8}{|c|}{ Fungal DNA in dust (target copies/g dust) } \\
\hline Asp/Pen DNA & $\begin{array}{l}1.26 \\
(0.38-4.20)\end{array}$ & $\begin{array}{l}1.34 \\
(0.53-3.34)\end{array}$ & $0.99(0.48-2.04)$ & $1.18(0.47-3.00)$ & $1.80(0.54-5.97)$ & $1.41(0.77-2.57)$ & $\begin{array}{l}1.24 \\
(0.97-1.57)^{(*)}\end{array}$ \\
\hline $\begin{array}{l}\text { A. versicolor } \\
\text { DNA }\end{array}$ & $\begin{array}{l}1.57 \\
(1.14-2.17)^{* *}\end{array}$ & $\begin{array}{l}1.43 \\
(1.09-1.99)^{*}\end{array}$ & $1.20(0.79-1.63)$ & $1.14(0.79-1.63)$ & $\begin{array}{l}1.79 \\
(1.19-2.69)^{* *}\end{array}$ & $1.27(1.01-1.61)^{*}$ & $1.12(1.02-1.23)^{*}$ \\
\hline $\begin{array}{l}\text { Streptomyces } \\
\text { DNA }\end{array}$ & $\begin{array}{l}1.13 \\
(0.82-1.55)\end{array}$ & $\begin{array}{l}0.78 \\
(0.46-1.32)\end{array}$ & $0.91(0.67-1.24)$ & $1.27(0.95-1.71)$ & $1.2(0.73-1.42)$ & $0.90(0.69-1.17)$ & $1.00(0.92-1.09)$ \\
\hline $\begin{array}{l}\text { Total fungal } \\
\text { DNA }\end{array}$ & $\begin{array}{l}1.25 \\
(0.61-2.52)\end{array}$ & $\begin{array}{l}1.13 \\
(0.64-1.98)\end{array}$ & $0.83(0.54-1.27)$ & $1.23(0.70-2.16)$ & $1.31(0.64-2.75)$ & $1.21(0.85-1.74)$ & $\begin{array}{l}1.13 \\
(0.99-1.31)^{(*)}\end{array}$ \\
\hline
\end{tabular}

Asp/Pen: Aspergillus/Penicillium, A. versicolor: Aspergillus versicolor.

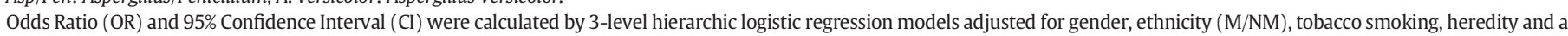
history of atopy.

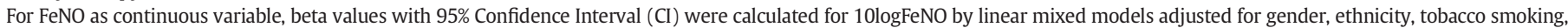
heredity and a history of atopy. Data in the table are antilog-values.

(OR calculated for $1000 \mathrm{mg}$ increase in fine dust).

(OR calculated for $10^{5}$ target copies/g dust increase in total fungal DNA in vacuumed dust).

(OR calculated for $10^{5}$ target copies/g dust increase in Asp/Pen DNA in vacuumed dust).

(OR calculated for 100 target copies/g dust increase in A. versicolor DNA in vacuumed dust).

(OR calculated for 10 target copies/g dust increase in Streptomyces DNA in vacuumed dust).

a Current asthma medication, asthma attacks last 12 months or wheeze with breathlessness last 12 months.

$* P=0.05$

$* p<0.05$.

** $p<0.01$. 
Table 5

Not in the article, in text mutual models $(p<0.1)$ with home environment (ETS + mould/damp).

\begin{tabular}{|c|c|c|c|c|c|}
\hline Type of exposure & $\begin{array}{l}\text { Wheeze } \\
\text { OR }(95 \% \text { CI })\end{array}$ & $\begin{array}{l}\text { Current asthma } \\
\text { OR }(95 \% \mathrm{CI})^{\mathrm{a}}\end{array}$ & $\begin{array}{l}\text { Respiratory infections } \\
\text { OR }(95 \% \mathrm{CI})\end{array}$ & $\begin{array}{l}\text { Elevated FeNO (>20 ppb) } \\
\text { OR }(95 \% \mathrm{CI})\end{array}$ & $\begin{array}{l}\text { Antilog FeNO } \\
\text { beta }(95 \% \mathrm{CI})\end{array}$ \\
\hline Amount of fine dust & $0.87(0.72-1.04)$ & $0.83(0.68-1.02)$ & NA & NA & NA \\
\hline A. versicolor DNA vacuumed dust & $1.48(1.08-2.01)^{*}$ & $1.37(1.01-1.88)^{*}$ & $1.77(1.18-2.65)^{* *}$ & $1.27(1.01-1.61)^{*}$ & $1.10(1.06-1.22)^{*}$ \\
\hline Asp/Pen DNA vacuumed dust & NA & NA & NA & NA & $1.13(0.88-1.45)$ \\
\hline Total DNA vacuumed dust & NA & NA & NA & NA & $1.08(0.93-1.26)$ \\
\hline
\end{tabular}

Asp/Pen: Aspergillus/Penicillium, A. versicolor: Aspergillus versicolor.

$\mathrm{NA}=$ Not included in the final models since $p>0.1$ in the previous models in Table 4.

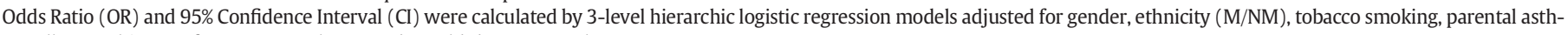
ma/allergy, a history of atopy, ETS at home and mould/dampness at home.

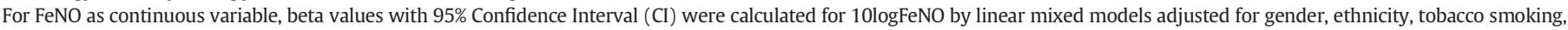
parental asthma/allergy, a history of atopy, ETS at home and mould/dampness at home. Data in the table are antilog-values.

(OR calculated for $1000 \mathrm{mg}$ increase in fine dust).

(OR calculated for $10^{5}$ target copies/g dust increase in total fungal DNA in vacuumed dust)

(OR calculated for $10^{5}$ target copies/g dust increase in Asp/Pen DNA in vacuumed dust).

(OR calculated for 100 target copies/g dust increase in $A$. versicolor DNA in vacuumed dust).

(OR calculated for 10 target copies/g dust increase in Streptomyces DNA in vacuumed dust).

a Current asthma medication, asthma attacks last 12 months or wheeze with breathlessness last 12 months.

* $p<0.05$.

** $p<0.01$.

leakage in the ceiling but we could not observe visible mould growth on indoor surfaces. However, it is possible that the water leakage in the ceilings had caused fungal growth inside the building construction. Students in classroom with signs of dampness had more often airway infections (OR $=3.70)$ and $31 \%$ higher levels of FeNO and these associations remained significant in mutually adjusted models with additional adjustment for home environment factors.

We found two previous school environment studies on associations between observed dampness in schools and respiratory health. One prevalence study from Shanghai, China, found that students in schools with observed indoor mould growth had more often asthma attacks $(\mathrm{OR}=2.40)$ (Mi et al., 2006). Moreover, a school study performed in schools in Finland, the Netherlands and Spain found an association between observed moisture damage in the schools and nocturnal dry cough in across the three countries $(\mathrm{OR}=1.15)$. Moreover, Finnish children attending moisture-damaged schools had more often wheeze $(\mathrm{OR}=1.36)$, nasal symptoms $(\mathrm{OR}=1.34)$ and respiratory-related school absence ( $O R=1.50$ ) (Borras-Santos et al., 2013). However, we found no previous study investigating associations between observed dampness in schools ad FeNO, an objective marker of lower airway inflammation.

Fungal DNA from Aspergillus versicolor in the classrooms was positively associated with current wheeze, current asthma, airway infections and FeNO levels. The association between this mould species and respiratory symptoms is in agreement with a previous school study from another part of Malaysia (Johor Bahru) (Cai et al., 2011; Norbäck et al., 2014). Moreover, a similar association between A. versicolor DNA in vacuumed dust from classrooms and asthmatic symptoms among pupils have been reported from a European school environment study (Simoni et al., 2011). A. versicolor is often found in damp buildings and produces the mycotoxin sterigmatocystin (Bloom et al., 2007). We found no previous school environment study on associations between fungal DNA and FeNO but one previous study found positive association between levels of fungal DNA in dust in day care centers and FeNO in day care center staff (Norbäck and Cai, 2015).

Our study has some strengths and limitations. One strength is that it consisted of a random sample of schools, classrooms and students within a defined area. However, the limited number of schools limits the external validity. Another strength is that dampness in the classrooms was assessed by independent inspection by trained staff and moreover we analysed fungal DNA as an objective marker of the amount of different types of mould in the classrooms, and included adjustments for indoor factors in the home environment. Finally, assessing not only questionnaire data on respiratory but also an objective marker of lower airway inflammation (FeNO) is a strength of the study by limiting the problem with recall bias.

Particles in indoor environments can be sampled by different methods. We sampled dust by vacuuming of floors and upper horizontal surfaces (desks and chairs). By vacuuming we can collect dust from all parts of the classrooms and collect a wide range of particle size fractions and we get enough dust to analyse different types of components. The disadvantage is that some of the collected particles are large and may not become airborne and thus not inhaled by the students.

We used the number of target copies per gram dust, as a proxy variable for the exposure to mould in the classroom. One advantage with molecular methods for detecting indoor mould is that a large number of species can be detected irrespectively of the viability of the fungal spores. A disadvantage is that there can be more than one target DNA copy per cell, and the number of copies per cell can vary between fungal species. However, the variation of number of target copies per cell is most likely to result in a non-differential misclassification of the mould exposure since it is unlikely that the number of target copies per cell is related to the potential to cause adverse health effects. Moreover, varying extraction efficiency for different species, or for different extraction methods, is another potential weakness of qPCR. The need of optimizing the extraction method for fungal DNA has been demonstrated for specific primers (Yamamoto et al., 2010) but the magnitude of this problem is not known for universal DNA sequences.

The response rate was reasonable for a study including clinical tests. All samples were analysed after questionnaire data was completed, and environmental sampling was conducted the same week as the questionnaire study. Moreover, the students did not have any information on the results of the environmental measurements when they answered the questionnaires. Since Penang has a similar climate all year around, ventilation flow or indoor levels of pollutants would be expected to be constant throughout the year. Thus we conclude that the study was not seriously influenced by selection or information bias. However, the cross-sectional study design limits the possibility to draw conclusions on causality.

\section{Conclusions}

Our study found that respiratory symptoms were common among the students and the elevated FeNO levels, even among students without doctors' diagnosed asthma, indicate an ongoing lower airway inflammation. Dampness in the classroom and the mould Aspergillus versicolor in schools in Malaysia can be risk factors for impaired 
respiratory health. More studies are needed on associations between fungal exposure and respiratory health in the tropics.

\section{Conflict of interest}

The authors declare that they have no conflict of interest.

\section{Acknowledgements}

This study was supported by grants from the Swedish Council for Environmental and Agricultural Science and Spatial Planning (FORMAS) (2008-68), the Swedish Asthma and Allergy Association's Research Foundation (2013020) and the Swedish International Development Agency (SIDA) (348-2013-6762).

\section{References}

Alving, K., Malinovschi, A., 2010. Basic aspects of exhaled nitric oxide. In: Horvath, I., de Jongste, J.C. (Eds.), Exhaled Biomarkers. European Respiratory Society, Plumouth, pp. 1-32.

Asher, M.I., Montefort, S., Björkstén, B., Lai, C.K., Strachan, D.P., Weiland, S.K., et al., 2006. Worldwide time trends in the prevalence of symptoms of asthma, allergic rhinoconjunctivitis, and eczema in childhood: ISAAC phase one and three repeat multicountry cross-sectional surveys. Lancet 368, 733-743.

Bloom, E., Bal, K., Nyman, E., Must, A., Larsson, L., 2007. Mass spectrometry-based strategy for direct detection and quantification of some mycotoxins produced by Stachybotrys and Aspergillus spp. in indoor environments. Appl. Environ. Microbiol. 73, 4211-4217.

Borras-Santos, A., Jacobs, J.H., Täubel, M., Haverinen-Shaoughnessy, U., Krop, E.J., Huttunen, K., et al., 2013. Dampness and mould in schools and respiratory symptoms in children: the HITEA study. Occup. Environ. Med. 70, 681-687.

Cai, G.H., Hashim, J.H., Hashim, Z., Ali, F., Bloom, E., Larsson, L., et al., 2011. Fungal DNA, allergens, mycotoxins and associations with asthmatic symptoms among pupils in schools from Johor Bahru, Malaysia. Pediatr. Allergy Immunol. 22, 290-297.

Daisey, J., Angell, W., Apte, M., 2003. Indoor air quality, ventilation and health symptoms in schools: an analysis of existing information. Indoor Air 13, 53-64.

Dweik, R.A., Boggs, P.B., Erzurum, S.C., Irvin, C.G., Leigh, M.W., Lundberg, J.O., et al., 2011. An official ATS clinical practice guideline: interpretation of exhaled nitric oxide levels (FENO) for clinical applications. Am. J. Respir. Crit. Care Med. 184, 602-615.

Haugland, R.A., Varma, M., Wymer, L.J., Vesper, S.J., 2004. Quantitative PCR analysis of selected Aspergillus, Penicillium and Paecilomyces species. Syst. Appl. Microbiol. 27, 198-210.

Janson, C., Anto, J., Burney, P., Chinn, S., de Marco, R., Heinrich, J., et al., 2001. The European Community Respiratory Health Survey: what are the main results so far? Eur. Respir. J. 18, 598-611.

Lim, F.L., Hashim, Z., Md Said, S., Than, L.T., Hashim, J.H., Norbäck, D., 2015. Sick building syndrome (SBS) among office workers in a Malaysian university- associations with atopy, fractional exhaled nitric oxide (FeNO) and the office environment. Sci. Total Environ. 536, 353-361.
Lim, F.L., Hashim, Z., Md Said, S., Than, L.T., Hashim, J.H., Norbäck, D., 2016. Fractional exhaled nitric oxide (FeNO) among office workers in an academic institution, Malaysia associations with asthma, allergies and office environment. J. Asthma 53, 170-178.

Mi, Y.H., Norbäck, D., Tao, J., Mi, Y.L., Ferm, M., 2006. Current asthma and respiratory symptoms among pupils in Shanghai, China: influence of building ventilation, nitrogen dioxide, ozone, and formaldehyde in classrooms. Indoor Air 16, 454-464.

Norbäck, D., Cai, G.H., 2011. Fungal DNA in hotel rooms in Europe and Asia - associations with latitude, precipitation, building data, room characteristics and hotel ranking. J. Environ. Monit. 10, 2895-2903.

Norbäck, D., Cai, G.H., 2015. Dampness, indoor mould, fungal DNA and respiratory health - molecular methods in indoor epidemiology. Clin. Exp. Allergy 45, 840-843 (editorial).

Norbäck, D., Björnsson, E., Janson, C., Palmgren, U., Boman, G., 1999. Current asthma and biochemical signs of inflammation in relation to building dampness in dwellings. Int J. Tuberc. Lung Dis. 3, 368-376.

Norbäck, D., Markowicz, P., Cai, G.H., Hashim, Z., Ali, F., Zheng, Y.W., et al., 2014. Endotoxin, ergosterol, fungal DNA and allergens in dust from schools in Johor Bahru, Malaysia-associations with asthma and respiratory infections in pupils. PLoS One 11, e883303.

Norbäck, D., Cai, G.H., Kreft, I., Lampa, E., Wieslander, G., 2016a. Fungal DNA in dust in Swedish day care centres: associations with respiratory symptoms, fractional exhaled nitric oxide (FeNO) and C-reactive protein (CRP) in serum among day care centre staff. Int. Arch. Occup. Environ. Health 89, 331-340.

Norbäck, D., Hashim, J.H., Cai, G.H., Hashim, Z., Ali, F., Bloom, E., Larsson, L., 2016b. Rhinitis throat and dermal symptoms, headache and tiredness among students in schools from Johor Bahru, Malaysia: associations with fungal DNA and mycotoxins in classroom dust. PLoS One 11, e01479976.

Salo, P.M., Sever, M.L., Zelin, D.C., 2009. Indoor allergens in school and day care environments. J. Allergy Clin. Immunol. 124, 185-192.

Simoni, M., Cai, G.H., Norback, D., Annesi-Maesano, I., Lavaud, F., Sigsgaard, F., et al., 2011 Total viable moulds and fungal DNA in classrooms and associations with respiratory health and pulmonary function of European schoolchildren. Pediatr. Allergy Immunol. 22, 843-852.

Smedje, G., Norbäck, D., Edling, C., 1997. Asthma among secondary school children in relation to the school environment. Clin. Exp. Allergy 27, 1270-1278.

Vesper, S.J. Wymer, LJ., Meklin, T, Varma, M. Stott, R, Richardson, M. et al, 2005. Comparison of populations of mould species in homes in the UK and USA using mouldspecific quantitative PCR. Lett. Appl. Microbiol. 41, 367-373.

WHO Regional office for Europe, 2009. WHO Guidelines for Indoor Air Quality: Dampness and Mould. Copenhagen and Bonn: WHO Regional office for Europe. Available at http://www.euro.who.int/documente92645.pdf (assessed January 2009).

Xu, F., Zou, Z., Yan, S., Li, F., Kan, H., Norback, D., et al., 2011. Fractional exhaled nitric oxide in relation to asthma, allergic rhinitis, and atopic dermatitis in Chinese children. J. Asthma 48, 1001-1006.

Yamamoto, N., Kimura, M., Matsuki, H., Yanagisawa, Y., 2010. Optimization of a real-time PCR assay to quantify airborne fungi collected on a gelatin filter. J. Biosci. Bioeng. 109, 83-88.

Zhao, Z., Sebastian, A., Larsson, L., Wang, Z., Zhang, Z., Norbäck, D., 2008. Asthmatic symptoms among pupils in relation to microbial dust exposure in schools in Taiyuan, China. Pediatr. Allergy Immunol. 19, 455-465.

Zhao, Z., Huang, C., Zhang, X., Xu, F., Kan, H., Song, W., et al., 2013. Fractional exhaled nitric oxide in Chinese children with asthma and allergies-a two-city study. Respir. Med. $107,161-171$ 